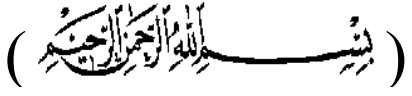

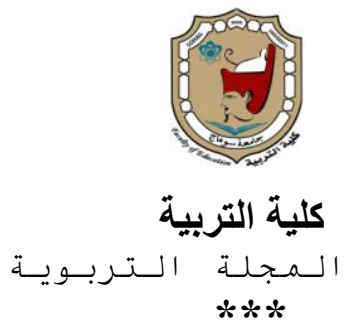

An Evaluation of Using the Phonic Approach in Teaching English to Primary School

\title{
Students in Kuwait
}

$$
\text { إعداد }
$$

First Author

Dr. Hanan Taqi

Co-Authors

Dr. Salwa Aldarwish

Dr. TaibaSadeq

Dr. BadriaAlhaji

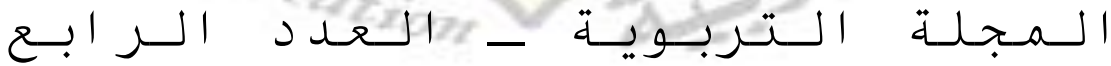

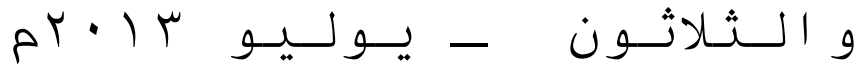


يقوم البحث على دراسة طرق تدريس الأصوات لتعليم القراءة. يقوم البحث على

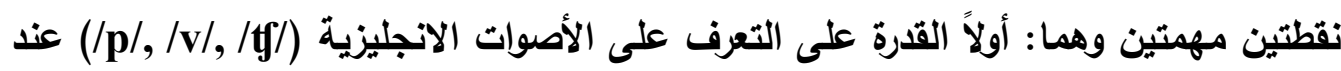

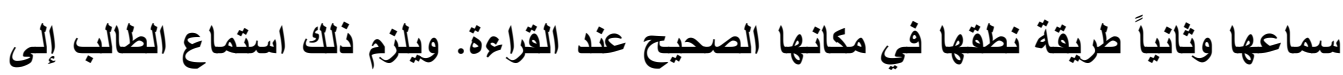
مقاطع في اللغة الانجليزية، وفي نفس الوقت قراعة نطاءة قصة باللغة الانجليزية.

وكاتت خطة البحث قائمة على حصر لطرق التدريس المستخدمة في تدريس القراعة باللغة الإنجليزية لأطفال المدارس الابتدائية بمدارس الكويت العامة، والتي أثشارت إلى مزايا وعيوب طرق التدريس. وقد تم اختيار العينة عشوائيا من عدة مدارس كويتية(وقد تم اختيار

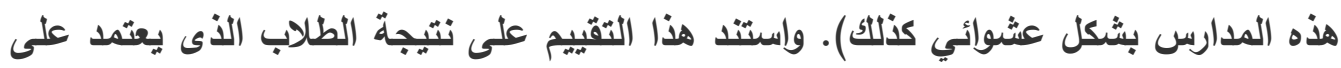

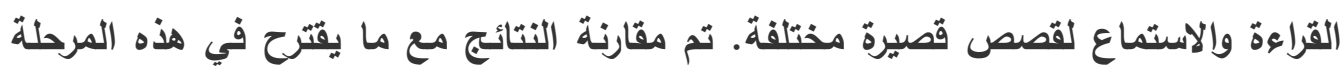
من قبل أسس التعليم الدولية في هذا المجال.

كان من المتوقع أن هذه الدراسة من شأنها أن تفيد فى التعرف على الأساليب

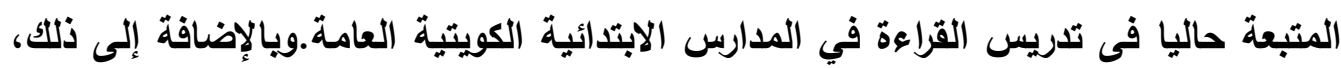
التأكيا على ان هناك فروق فى الارجات بين الجنسين.وتناولت الدراسة عيوب الطرق الحالية المتبعه في تدريس القراعة كطريقة تعلم الأصوات في المدارس الابتدائية الحكومية في

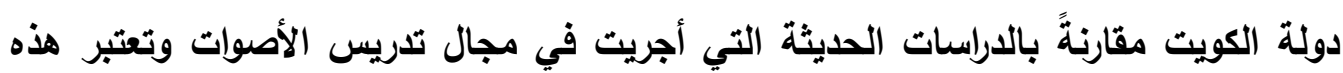

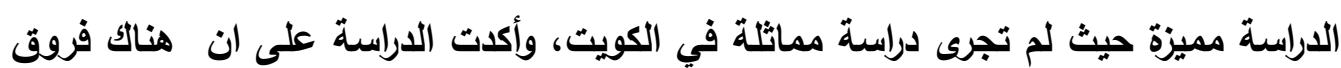
فى التعليم بين الجنسين. 


\section{Abstract:}

The current study aimed at investigating the characteristics of the phonic-based approach and seeking to show two points: the first was the students' ability to recognize the English sounds (/p/, /v/, $/ \mathfrak{y} /$ ) when heard (which will be tested by reading to children). The second point was the ability to realize these sounds while reading.

The researchers determined to overview the teaching methods that are actually used in teaching reading in English to primary school children in Kuwaiti public schools, and hence they pinpointed their advantages and disadvantages. The subjects sample were chosen randomly from several Kuwaiti public schools (the schools were chosen randomly as well). This evaluation was based on the students' results which depended on the reading and listening of two different short stories. The results were then compared to what is suggested at that stage by international educationists in the field.

It was expected that this study would result in the identification of the current methods of teaching reading in the Kuwaiti pubic primary schools. In addition, it emphasized the differences between genders and grades. The flaws of the current methods of teaching phonics in the public primary schools in Kuwait were addressed in connection to the recent studies conducted in the field of phonological awareness. This study is believed to be so authentic as the teaching of phonics has not been investigated previously in Kuwait, and gender-segregation in teaching phonics was greatly emphasized.

\section{Key words: phonic awareness, teaching methods, gender, segregation}

\section{The research questions are as follows:}

1. Are first and second grade students able to identify and read the English sounds $(/ \mathrm{p} /, / \mathrm{v} /, / \mathrm{t} /)$ ? 
2. Is there a difference between male and female students' ability to identify and read the sounds addressed?

\section{Literature Review:}

Teaching phonics to children enables them to read and write in either their mother tongue or a second language and it is not considered a new concept. It is a concept which faced lots of controversy, pros and cons. The following review will discuss these points:

1. The definition of the phonic/decoding approach.

2. The main goals of teaching by the phonics approach.

3. The different types of methods proposed by the phonic approach.

4. Identification of the approach proposed by the new syllabus in Kuwait.

Teaching children to read at an early stage has been shown, in different studies, to have more advantages in language learning. Steinberg and Sciarini (2006:89) believed that children are ready to read by the age of two. This was supported by the belief that at this age, the child has accumulated a sufficient amount of knowledge of words and phonics in their first language (ibid). Most studies support the fact that children learn to read in an early age, which in turn supports their language learning (Terman, 1918; Fowler, 1962; Doman, 1964; Thompson, 2000; and many more).

The phonic-based approach in teaching reading, namely the decoding approach, is an approach which believes that language can be learned by converting written forms into speech forms, and then it is translated into meaning (Ehri, 1991). In other words, when a child is taught using the phonic approach, he/she will be able to recognize the sound value of each letter and letter combination. Therefore, it is believed that the learner will be able to read the whole word regardless of knowing the meaning. 
The phonic approach is currently practiced in many British schools. It is; therefore, should be assumed that the approach followed in the public schools in Kuwait follow similar procedures. Since the National Literary Strategy (NLS) was introduced in England in 1998, the implementation of the phonic approach spread significantly. The NLS encouraged the teaching of phonics regularly from the age of five.

Many researchers opposed the teaching of phonics on the grounds that it is illogical to emphasize small phonological units since even large units are considered important for reading (Johnston and Watson, 2005). However, the phonic approach advocates believe that most studies opposing phonics teaching have chosen the phonic method which is not suitable for their environment and/or culture, and the dialect and/or language being taught.

One of the well-known phonic methods of teaching is the synthetic approach. This approach depends on a systematic approach of teaching sounds in association with a particular grapheme (letter). Lewis and Ellis (2006:4) stated that in the analytic approach, the first step is teaching the sounds auditory in a spoken word and blending phonemes. For example, when trying to sound a single syllable word such as hen, the teacher sounds out each phoneme individually as / $h e n /$.

Analytic phonics, on the other hand, is based on the teaching of whole words, and then asking the learner to segment the words into individual phonemes. Students are also encouraged to identify similar sounds in other words (such as pan, can and fan) all end with the same phonemic combination /æn/. In this approach, students are represented with words and the words are pronounced by the instructor. Afterwards, the instructor starts segmenting words, and 
hence providing the phonic experience to the children (Lewis and Ellis, 2006:4).

It is found that most teachers follow an integrated approach -both synthetic and analytic. The approach implemented in Kuwait is the integrated approach. In the first grade teacher's guide (2010), the following points are stated:

1. Students must be aware of words that consist of a group of sounds.

2. The association of sounds and their orthographic representations should be made clear in the very beginning to students.

3. Correspondence of letters and their most common sounds are presented directly through games and activities.

The importance of teaching phonics and phonological awareness is stressed in second grade as well. In the teacher's guide (2010) for the second grade, it is stated that teaching phonics is considered the most appropriate way of teaching reading. A few games and activities have been suggested in the teachers' guides in both grades to teach phonics. It is worthy noted that primary schools in the state of Kuwait are segregated based on gender. This segregation commences from primary school and goes through to high school.

The aim of the current investigation is to analyze the effectiveness of this approach, and if not found positively effective, the reasons behind its failure to reach the proposed goal is then investigated.

\section{Delimits of the study:}

The study has only concentrated on a small group of students (40 students); a larger number of participants could provide better 


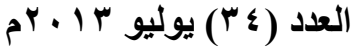

information and a clearer picture of the phonic situation. It might also help to study the environmental effect (home and social connections) to be able to identify more learning influences. It would be very helpful to distinguish the different backgrounds the informants come from in order to link the information provided with students' backgrounds.

\section{Methodology:}

As the study was addressing the non-native language of the students, spontaneous data could not be obtained. Instead, there were two methods of data collection:

1. Two stories were designed for first and second grade students to read. The readings were recorded by using an Edirol-09 for digital and high quality recordings.

2. A list of words with the English sounds $(/ \mathrm{p} /, / \mathrm{v} /, / \mathrm{t})$ was read to the students where the correct word had to be circled. The two words only differed by the use of the target English sounds, and the voiced/voiceless counter parts as follows: /p/ vs. /b/, /v/ vs. /f/ and /ft/ vs. / $/$.

The readings included 15 words; 5 words which included /p/, 5 words which included $/ \mathrm{y} /$ and 10 words which included /v/. The listening part included 10 words which included /p/, 10 which included / $/ \mathrm{v}$ and 10 which included $/ \mathrm{t} /$. The existence of the target sounds was based on one-syllable words. The letters appeared in these words are positioned either initially or finally. Some words were quoted from the textbooks of the same grade or from a previous grade (only for grade 2), while new words helped the researchers identify the students' abilities in reading.

The stories were presented on colorful A4 paper. The first story was accompanied by pictures that might help the reader identify words as a hint on one hand, and to make the story more interesting on the other hand. The second story was structured as a poem more than a story to avoid the boredom of repetitive 
presentations. The list of words was read slowly, while the answer sheet was also colorful and with big font.

The participants were chosen randomly from four primary schools in Kuwait - two female schools and two male schools. All subjects are Kuwaiti students who did not have any private education; therefore, have not studied the English language before going to school. The sample consisted of 20 male students who were interviewed. The sample was divided into two main groups, where 10 were second graders and 10 were third graders. The other sample consisted of 20 female students, who were interviewed; 10 were second graders and the other 10 were third graders. The students were chosen randomly from four different primary schools (5 students from each grade in each school), and each student was asked whether he/she had private education or studied English formally. The data was collected in three weeks commencing April 3, 2011 .

The data obtained was entered into SPSS tables and analyzed in terms of means, correlation and significance. Statistically, each data set is defined as a dependent variable, while the independent factors are grade and gender. The aim of a quantitative data analysis is to test the effect of the independent factors in the realization of the phonological variables. The data was set into number values at first, and then converted into a scale of 100 (percentage) to facilitate the use of different SPSS features. Because the data is set in a scale (percentages of $\mathrm{N}$ ), and is thus equal, an ANOVA test was found suitable for this in addition to the other types of analysis used. The p>0.05 value is calculated through the F-statistic to show significance.

\section{Results:}

Students in general seemed to have difficulty in realizing the sounds of English. The statistical results showed that the mean percentage of students who are able to realize the /p/ was \%38.95. This was the sound most realized when compared to $/ \mathrm{v} /$ and $/ \mathrm{t} /$; 


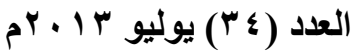

where the mean percentage for $/ \mathrm{v} /$ realization was $\% 36.25$ and the mean scores of realization for $/ \mathrm{f} /$ realization was the least $(\% 27.75)$. Therefore, overall, less than half the words in the study were realized by the students participating in the study.

When comparing the realizations of male and female students, it is obvious from the data collected that female students exceed male students in their ability to realize the English sounds under investigation. The following Table shows the percentage of realizations according to gender.

Table 1

The realization of English sounds by gender

\begin{tabular}{|ll|l|l|l|}
\hline gender & & frealisation & $\begin{array}{c}\mathrm{v} \\
\text { realisation }\end{array}$ & $\begin{array}{c}\mathrm{p} \\
\text { realisation }\end{array}$ \\
\hline male & Mean & 2.50 & 20.00 & 23.20 \\
& N & 20 & 20 & 20 \\
& $\begin{array}{l}\text { Std. } \\
\text { Deviation }\end{array}$ & 7.864 & 11.239 & 7.381 \\
\hline female & Mean & $\mathbf{5 3 . 0 0}$ & 52.50 & 54.70 \\
& N & 20 & 20 & 20 \\
& $\begin{array}{l}\text { Std. } \\
\text { Deviation }\end{array}$ & 22.734 & 14.824 & 12.282 \\
\hline Total & Mean & 27.75 & 36.25 & 38.95 \\
& N & 40 & 40 & 40 \\
& Std. & 30.591 & 20.962 & 18.827 \\
Deviation & & &
\end{tabular}

The table above (Table 1) shows that while a mere \%23.2 of the male students was able to realize the /p/ sound; $\% 54.70$ of the female participants identified the same sounds. The significance of which was calculated by a one-way ANOVA by gender in the realization of $/ \mathrm{p} /$ and showed $F(1,40)=96.646$. $p>0.001$ (see Table 2 below). As for the /v/ results, (reflected in Tables 1 and 2). Male students realized $\% 20$ of the sounds presented in the stories as opposed to $\% 52.5$ of the female realizations. The ANOVA test 


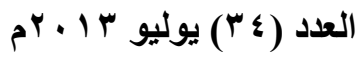

showed that the difference between male and female speakers in the realization of $/ \mathrm{v} /$ is highly significant $(F=(1,40) 61.046$, and $p>0.001)$. Finally, in the realization of the $/ \mathrm{tg} / \mathrm{sound}$, the one-way ANOVA test showed the realizations of $/ \mathrm{t} / \mathrm{by}$ both genders to be significant where $F(1,40)=88.140$, and $p>0.001$ ( $p=0.05$ level $)$.

Table 2

Significance of the realization of English sounds by gender

\begin{tabular}{|c|c|c|c|c|c|c|}
\hline $\begin{array}{l}\text { Realization } \\
\text { of gender }\end{array}$ & & $\begin{array}{l}\text { Sum of } \\
\text { Squares }\end{array}$ & df & Mean Square & $\mathbf{F}$ & Sig. \\
\hline tf realisation & $\begin{array}{l}\text { Between } \\
\text { Groups }\end{array}$ & 25502.500 & 1 & 25502.500 & 88.140 & .000 \\
\hline & Within Groups & 10995.000 & 38 & 289.342 & & \\
\hline & Total & 36497.500 & 39 & & & \\
\hline v realisation & $\begin{array}{l}\text { Between } \\
\text { Groups }\end{array}$ & 10562.500 & 1 & 10562.500 & 61.046 & .000 \\
\hline & Within Groups & 6575.000 & 38 & 173.026 & & \\
\hline & Total & 17137.500 & 39 & & & \\
\hline p realisation & $\begin{array}{l}\text { Between } \\
\text { Groups }\end{array}$ & 9922.500 & 1 & 9922.500 & 96.646 & .000 \\
\hline & Within Groups & 3901.400 & 38 & 102.668 & & \\
\hline & Total & 13823.900 & 39 & & & \\
\hline
\end{tabular}

Meanwhile, female students have also shown a better ability to identify the English sounds than male students. As seen in Table 3 below, \%52 of female students were able to identify /p/ sounds as opposed to \%19.5 of the male students. In addition, /v/ was identified by $\% 69$ of the female participants and only $\% 36$ of the male participants. As for $/ \mathrm{t} /, \% 70$ of the female students was able to identify it, while only $\% 19.5$ of the male students identified it. 


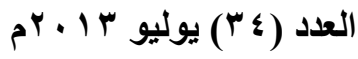

\section{Table 3}

Percentage of the identification of English sounds by gender

\begin{tabular}{|ll|l|l|l|}
\hline gender & & ch identification & v identification & p identification \\
\hline male & Mean & 19.50 & 36.00 & 36.00 \\
& N & 20 & 20 & 20 \\
& Std. Deviation & 10.990 & 8.208 & 8.826 \\
\hline female & Mean & 70.00 & 69.00 & 71.50 \\
& N & 20 & 20 & 20 \\
& Std. Deviation & 14.510 & 15.526 & 13.485 \\
\hline Total & Mean & 44.75 & 52.50 & 53.75 \\
& N & 40 & 40 & 40 \\
& Std. Deviation & 28.554 & 20.724 & 21.206 \\
\hline
\end{tabular}

The difference between the realization of male and female speakers of the English sounds has shown to be significant. A oneway ANOVA test for the significance in the identification of the $/ \mathrm{p} /$ sound showed that $F(1,40)=97.041$ and $p>0.001$. In the same respect, the identification of $/ \mathrm{v} /$ was significant by gender where $F(1,40)=70.618$ and $p>0.001$. The realization of $/ \mathrm{g} /$ was not very different. The realization of $/ \mathrm{t} / \mathrm{h}$ has showed to be highly significant where in a one-way ANOVA by gender $F(1,40)=153.947$, and $\mathrm{p}>0.001$.

The final question addressed in this analysis of data was concerned with the student participants' grade. It was assumed that third graders have improved their phonological awareness, and therefore, exceeded the second graders in their ability to realize and identify the English sounds. Chart 1 below shows the realization of the English sounds by grade. 


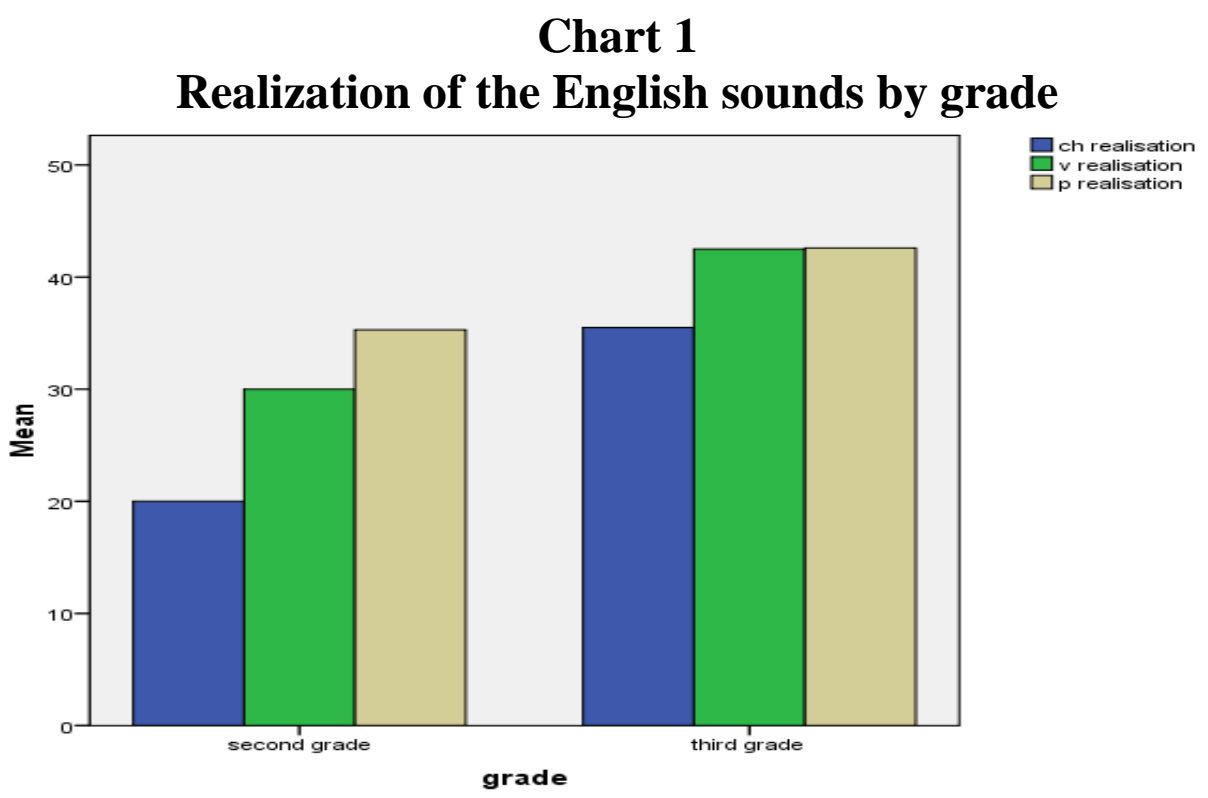

Third graders have shown the ability to realize the English sounds more than the second graders. In a one-way ANOVA by grade test, there was no significance in the realization of the three English sounds $/ \mathrm{p} /, / \mathrm{v} /, / \mathrm{t} /$ respectively (for $/ \mathrm{p} / F(1,40)=1.524$, $p=0.225 ;$ for $/ \mathrm{v} / F(1.40)=3.812, p=0.058$; for $/ \mathrm{g} / F(1.40)=2.678$, $p=0.225$ ).

A more detailed analysis of the realization data shows that although generally there is no significance between second and third graders in the realization of the three English sounds, there is significance in some cases when it comes to a two-way ANOVA by gender by grade test. The significance is shown in two sounds only: $/ \mathrm{v} /$ and $/ \mathrm{g} /$. For $/ \mathrm{v} / F(1,20)=13.709$ and $p=0.002$; and for $/ \mathrm{g} /$ $F(1,20)=10.447$ and $p=0.005$. However, no significance can be found in $/ \mathrm{p} /$ where $F(1,20)=4.388$ and $p=.06$. On the other hand, no significance in the realization of the three English sounds was found by grade in the male group. 


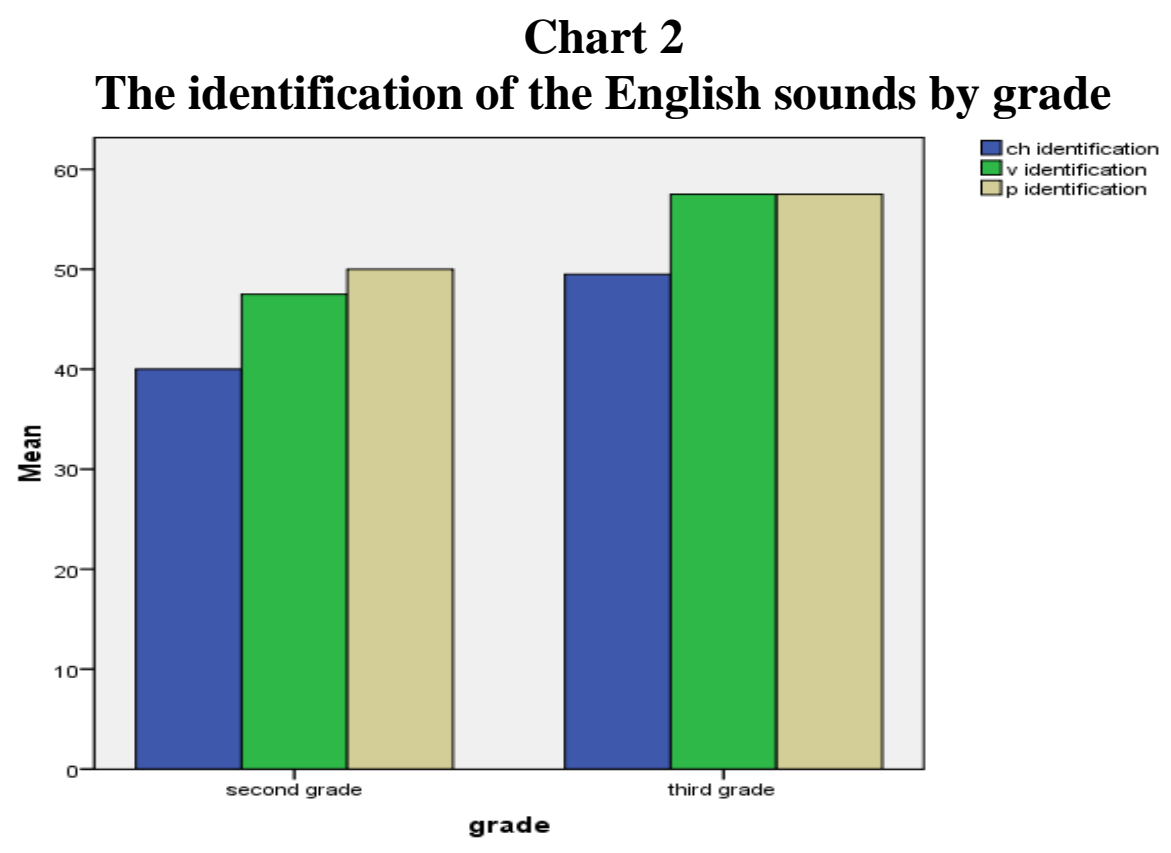

Does the identification of sounds differ according to grade? Statistics showed that the mean of the identification of the $/ \mathrm{p} /$ sound among second graders was $\% 50$ and among third graders $57.5 \%$. In addition, third graders were able to identify /v/ more than second graders by $\% 10$. As for $/ \mathfrak{t} /, \% 40$ of the second graders were able to identify the $/ \mathrm{t} / \mathrm{s}$ sound in words they heard, while $\% 49.5$ of the third graders were able to identify them. Nevertheless, this difference was not significant.

The same data information was analyzed by grade and gender. The percentage of the male second graders who can identify the $/ \mathrm{p} /$ sound was $\% 33$ and third graders \%39. As for the $/ \mathrm{v} /$ sound, $\% 34$ of the male second graders was able to identify it and \%38 of the third graders. $\% 19$ of the $/ \mathfrak{t} /$ sounds were identified by the second graders and $\% 20$ of the sounds were identified by the third graders. The percentages are shown in Table 3 below. 


\section{Chart 3}

The percentages of the identification of English sounds in the male group by grade

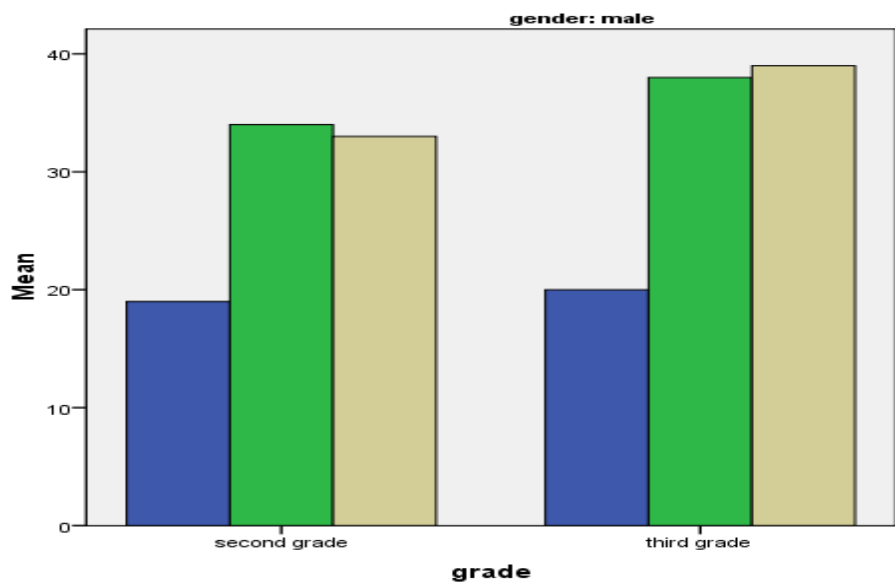

Ch identification $\square_{p}^{v}$ identification

There was no significance in the identification of the English sounds $/ \mathrm{v} /$ and $/ \mathrm{t} /$ by the male participants in terms of grade; however, significance was found in the identification of the $/ \mathrm{p} /$ sound between grades. This was tested in a one-way ANOVA by grade for $/ \mathrm{p} /, / \mathrm{v} /$ and $/ \mathrm{t} /$ respectively: $\mathrm{F}(1,20)=0.039$ and $\mathrm{p}=0.845$; $\mathrm{F}(1,20)=1.200$ and $\mathrm{p}=0.288$; and $\mathrm{F}(1.20)=2.492$ and $\mathrm{p}=0.132$.

As for the identification of the English sounds in the female group, \%67 of the second graders was able to identify the /p/ sound as opposed to $\% 76$. Moreover, in the second grade $\% 61$ of the $/ \mathrm{v} /$ sound were identified and only $\% 77$ of them were identified by the female third graders. Finally, $\% 61$ of the $/ \mathrm{t} /$ sound were identified by the second graders and $\% 79$ of the third graders. Significance of the English sounds in the female groups by grade was calculated in a one-way ANOVA which can be seen in Table 4 below. 


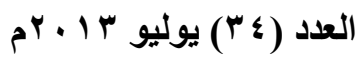

\section{Table 4}

Significance of the realization of English sounds by grade in the female group

\begin{tabular}{|c|c|c|c|c|c|c|}
\hline Gender & & $\begin{array}{c}\text { Sum of } \\
\text { Squares }\end{array}$ & df & Mean Square & $\mathbf{F}$ & Sig. \\
\hline id & $\begin{array}{l}\text { Between } \\
\text { Groups } \\
\text { Within Groups } \\
\text { Total }\end{array}$ & \begin{tabular}{|}
1620.000 \\
2380.000 \\
4000.000
\end{tabular} & $\begin{array}{l}1 \\
18 \\
19\end{array}$ & $\begin{array}{l}1620.000 \\
132.222\end{array}$ & 12.252 & .003 \\
\hline $\begin{array}{l}\mathbf{v} \\
\text { identification }\end{array}$ & $\begin{array}{l}\text { Between } \\
\text { Groups } \\
\text { Within Groups } \\
\text { Total }\end{array}$ & \begin{tabular}{|l}
1280.000 \\
3300.000 \\
4580.000
\end{tabular} & $\begin{array}{l}1 \\
18 \\
19\end{array}$ & $\begin{array}{l}1280.000 \\
183.333\end{array}$ & 6.982 & .017 \\
\hline $\begin{array}{l}\mathbf{p} \\
\text { identification }\end{array}$ & $\begin{array}{l}\text { Between } \\
\text { Groups } \\
\text { Within Groups } \\
\text { Total }\end{array}$ & \begin{tabular}{|l}
405.000 \\
3050.000 \\
3455.000
\end{tabular} & $\begin{array}{l}1 \\
18 \\
19\end{array}$ & $\begin{array}{l}405.000 \\
169.444\end{array}$ & 2.390 & .140 \\
\hline
\end{tabular}

a. gender $=$ female

From Table 4 above, one can see that there is no significance in the realization of /p/ by grade; yet, there is significance in the realization of the other two English sounds tested $/ \mathrm{v} /$, and $/ \mathrm{t} /$. For $/ \mathrm{v} /$ the one-way ANOVA by grade is shown to be $F(1,20)=6.982$ and $p=0.017$; while for $/ \mathfrak{t} /$ the one-way ANOVA by grade shows $F(1,20)=12.252$ and $p=0.003$, where $\mathrm{p}=0.05$. A two-way ANOVA by grade by gender shows that there was high significance in the realization of the English sounds $/ \mathrm{p} /, / \mathrm{v} /$ and $/ \mathrm{g} /$ in both grades as can be seen in the following Table(5). 


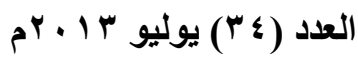

\section{Table 5}

Significance of the identification of English sounds by gender by grade

\begin{tabular}{|c|c|c|c|c|c|c|}
\hline & & $\begin{array}{c}\text { Sum of } \\
\text { Squares }\end{array}$ & df & Mean Square & $\mathbf{F}$ & Sig. \\
\hline $\begin{array}{l}\text { to } \\
\text { identification }\end{array}$ & $\begin{array}{l}\text { Between } \\
\text { Groups } \\
\text { Within Groups } \\
\text { Total }\end{array}$ & $\begin{array}{l}18722.500 \\
13075.000 \\
31797.500\end{array}$ & $\begin{array}{l}37 \\
39\end{array}$ & $\begin{array}{l}9361.250 \\
353.378\end{array}$ & 26.491 & .000 \\
\hline $\begin{array}{l}\mathbf{v} \\
\text { identification }\end{array}$ & $\begin{array}{l}\text { Between } \\
\text { Groups } \\
\text { Within Groups } \\
\text { Total }\end{array}$ & \begin{tabular}{|r|}
9605.000 \\
7145.000 \\
16750.000 \\
\end{tabular} & $\begin{array}{l}37 \\
39\end{array}$ & $\begin{array}{l}4802.500 \\
193.108\end{array}$ & 24.869 & .000 \\
\hline $\begin{array}{l}\text { p } \\
\text { identification }\end{array}$ & $\begin{array}{l}\text { Between } \\
\text { Groups } \\
\text { Within Groups } \\
\text { Total }\end{array}$ & \begin{tabular}{r|}
9267.500 \\
8270.000 \\
17537.500 \\
\end{tabular} & $\begin{array}{l}37 \\
39\end{array}$ & $\begin{array}{l}4633.750 \\
223.514\end{array}$ & 20.731 & .000 \\
\hline
\end{tabular}

A one-way ANOVA by gender was also calculated for each grade separately to measure significance between male and female participants in second grade and third grade. The results showed that there was high significance in the identification of sounds by male and female speakers in the second and third grade. Table 6 and 7 show the results of the one-way ANOVA by gender in the two grades separately. 


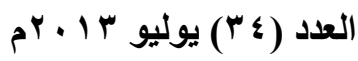

Table 6

Significance of the identification of English sounds by gender in the second grade

\begin{tabular}{|c|c|c|c|c|c|c|}
\hline & & $\begin{array}{c}\text { Sum of } \\
\text { Squares }\end{array}$ & df & Mean Square & $\mathbf{F}$ & Sig. \\
\hline tyidentification & $\begin{array}{l}\text { Between } \\
\text { Groups }\end{array}$ & 8820.000 & 1 & 8820.000 & 46.970 & .000 \\
\hline & Within Groups & 3380.000 & 18 & 187.778 & & \\
\hline & Total & 12200.000 & 19 & & & \\
\hline $\begin{array}{l}\mathbf{v} \\
\text { identification }\end{array}$ & $\begin{array}{l}\text { Between } \\
\text { Groups }\end{array}$ & 3645.000 & & & 20.962 & .000 \\
\hline & Within Groups & 3130.000 & 18 & 173.889 & & \\
\hline & Total & 6775.000 & 19 & & & \\
\hline $\begin{array}{l}\text { p } \\
\text { identification }\end{array}$ & $\begin{array}{l}\text { Between } \\
\text { Groups }\end{array}$ & 5780.000 & 1 & & 57.165 & .000 \\
\hline & Within Groups & 1820.000 & 18 & 101.111 & & \\
\hline & Total & 7600.000 & 19 & & & \\
\hline
\end{tabular}

\section{Table 6}

Significance of the identification of the English sounds by gender in the third grade

\begin{tabular}{|ll|r|r|r|r|r|}
\hline & & $\begin{array}{c}\text { Sum of } \\
\text { Squares }\end{array}$ & \multicolumn{1}{c|}{ df } & \multicolumn{1}{c|}{$\begin{array}{c}\text { Sean } \\
\text { Square }\end{array}$} & \multicolumn{1}{c|}{ F } & Sig. \\
\hline ch identification & Between Groups & 17405.000 & 1 & 17405.000 & 242.860 & .000 \\
& Within Groups & 1290.000 & 18 & 71.667 & & \\
& Total & 18695.000 & 19 & & & \\
\hline v identification & Between Groups & 7605.000 & 1 & 7605.000 & 99.920 & .000 \\
& Within Groups & 1370.000 & 18 & 76.111 & & \\
& Total & 8975.000 & 19 & & & \\
\hline p identification & Between Groups & 6845.000 & 1 & 6845.000 & 48.700 & .000 \\
& Within Groups & 2530.000 & 18 & 140.556 & & \\
& Total & 9375.000 & 19 & & & \\
\hline
\end{tabular}




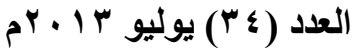

\section{Discussion:}

This study analyzed the ability to identify and realize the English sounds /p/, /v/, and / $\mathrm{g} /$ (which are not part of the Arabic sound system) by students who have finished first and second grade primary school, and are currently studying in second and third grades.

When speaking to the teachers, it seemed that most of them tried to teach phonic awareness to students by sounding out the letters while pointing at them only, as part of a lesson. Unfortunately, they were not aware of further methods of teaching phonics, such as team play, and action with sound method. None of the teachers made games with phonics. Some of the teachers stated that they only followed the guidelines written in the teachers' book. Thus, although many students displayed a noticeable amount of phonics awareness, they have been taught by pointing to the written form of the letter and sounding it out. It is believed that fun with phonics helps increase the amount of learning (Sever, 1994). In addition, systematic teaching of phonics, increases the learning dimensions greatly, and thus, teaching phonics should not be dealt with as a minor part of the curriculum.

All teachers agreed that they did not receive any sort of education in the field of phonics. None of the courses taught in college dealt with phonics. They, therefore, depended completely on what was written in the teachers' book, and they followed the instructions carefully. Many of the teachers, especially those who taught girls, noticed that the students who were partially aware of their phonics read better and displayed enthusiasm to reading when a considerable amount of phonics was learnt, as opposed to those who learned very little phonics. In effect, most teachers understood the value of teaching phonics to their students. However, teachers who taught in female schools were discouraged gradually because of the lack of interest on the boys' side. 
It was found in this study that girls have surpassed boys significantly in their ability to both realize and identify sounds. The issue of learning in general and language learning in specific in relation to gender has been the center of many studies. Most studies agreed that female students do better than male students in general (Feinglod, 1994; Ferrara, 2000; Costa et al, 2001). In a study conducted by the UNESCO - OCED (2003) on the average of male and female students' scores in different school grades, it was found that male students were consistently underachievers in comparison with girls. In this respect, it seemed as a must to understand what causes gender differences in learning a language.

Educational psychologists pinpointed many reasons behind the fact that girls are better learners than boys. At first, educational psychologists believed that the way children were raised determined the differences found between genders in the educational fields. In the past, girls hardly went out, and did not have enough freedom to socialize and leave their home. Therefore, it seemed reasonable to assume that girls studied more, and did not have many distractions at home or in school. However, this has been shown to be untrue since studies conducted in Europe and America have shown major personality gender difference even though they minimize the differences most (Cosat et al., 2001: 322). Nowadays, most Kuwaiti families raise their children beyond gender limitations, where there is less emphasis on gender in social life (Al-Naqeeb, 2003).Therefore, it is not logical to blame the methods of raising children when it comes to male underachievement.

By comparing the achievements of male and female students globally, it was found that girls do better in all subjects and constantly evaluate their performance (OCED, 2003). When it comes to language, educational psychologists found that there are gender differences in processing information, especially when it comes to language. Educational psychologists noticed that females process language in both hemispheres, while boys use only one hemisphere. This leads to the notion of teaching by gender. The 
teachers' guides distributed at the beginning of the academic year by the ministry of education stress certain methods of teaching; it also suggests activities for teachers to use in the classroom. Although it has been found that segregation builds a happier educational environment (Barton, 1996), the purpose of this segregation; namely catering for gender differences, is not emphasized. In the current study, when the boys' teachers were asked why only one student was able to realise $/ \mathrm{t} /$ although the affricate is introduced in the textbooks as being part of the English phonics, one of the teachers replied "it's because it's hard to make boys sit down and listen".

The issue of "catering" for gender specific needs is not discussed or even swiftly mentioned in the teachers' guides. In each grade, activities are suggested to all students, regardless of their gender. As there seems to be a significant difference between the girls' and boys' ability to identify and realize English sounds, there must be separate guides for boys and girls. These books should focus on gender differences and abilities. Girls, for instance, could spend a longer time listening and trying. Boys, on the other hand, prefer activities that involve movement and body activity. It is essential to remember that boys are impatient and stop paying attention in a short while. It is also worthwhile designing activities for boys that involve group work, as boys prefer to work as a team. Boys also like competitive games and perform better when the outcome is presented as "winning" a game rather than "learning" something new. Girls, on the other hand, like to work with their imagination and be creative (Wilkinson \&Marrett, 1985; Gentry et al., 2002; Eccles et al, 2008).

Differences were calculated in this study to show two-fold results: the general picture reflected no significance in the identification of the English sounds when calculated by grade. On the other hand, there was significance in the identification of the English sounds when the sounds are analyzed in a two-way ANOVA by gender and grade. When first grade females and males 
are compared in the amount of sounds they were able to identify, female speakers were always ahead. Yet, when comparing grades within a single grade, the results are different. In the male group, there is no significance in the identification of the English sounds. It is believed that the male group acquired very little in the first grade and did not show much advance in the second grade as well. However, there is significance in the identification of $/ \mathrm{t} /$ and $/ \mathrm{v} /$ between grades in the female group. This might be due to the fact that $/ \mathrm{p} /$ is one of the first sounds learned by young learners (as billable are the first sounds acquired by children due to the visibility and ease of its realization).

A one-way ANOVA by grade showed that there was no significance in the realization of English sounds between first and second graders in Kuwaiti primary schools. However, a two-way ANOVA by grade and gender represented a more detailed view. This analysis showed that when comparing participants from each grade individually in terms of gender, female students from both grades exceeded their counterparts in the male groups. The next step depended on the comparison of results within the same gender. While there was no significance in the amount of realizations of the English sounds among the female participants, significance was found in the realization of $/ \mathrm{p} /$ with-in the male group. The data, therefore, reflects the fact that labial sounds are acquired first due to its visual nature and the ease of imitation (Steinberg \&Sciarini, 2007). It appears that a significant number of male second graders has the ability to realize the /p/ sound when spotted in a story (39\%), while the other sounds were not recognized as much.

The ability to identify and realize a sound in some instances only is a matter that should be analyzed. One of the first main reasons is the fact that a few words, such as 'love', are part of the vocabulary taught in one or both grades. The more the students are exposed to the word, the better the ability to read them regardless of the ability to recognize the phonic representation of each letter. In addition, the words presented in the investigation contained the 
sounds word-initial word-final. The place of a sound does differ, where when students attempt to read a word, most stress is placed on the first sound. Moreover, when the sounds are read by the researchers, the participants (especially male participants) are most attentive in the beginning and lose patience eventually. Word choice, in addition, gives ample place for luck, as all the participants answered all the word-choice questions.

It is worth mentioning that many female participants displayed noticeable self- confidence when answering and answering the identification sheet. From first sight, the researchers were able to recognize the fact that the female participants had good phonic bases as opposed to the male participants. Many male students started the tasks by informing the researchers that they did not know how to read and could not answer questions in English.

Finally, Savage (2009:174) stated that recent longitudinal studies of reading acquisition have demonstrated that the acquisition of phonological awareness is highly predictive in learning to read. Conducting a study in the American public schools, Savage (ibid) found that $\% 80$ of the students who were taught reading through phonics, have been able to develop phonological awareness. When comparing the outcome obtained in this study, it seems that the results in the Kuwaiti primary schools are quite different. The percentage of phonological awareness in the first and second grades (calculated by obtaining the mean of the realization and identification of sounds) is approximately $\% 42$. Although the average score obtained by the female students was around \%52, the male participants had \%32 only. The difference between male and female participants has been addressed previously in detail above in this section; nonetheless, the question is: is \%52 good enough? When Savage (2009) wondered how to fill in the missing \%20 who have not been able to read through phonics, she was investigating a case of daily teaching of English to native speakers of the language. Students in the Kuwaiti primary schools receive 5 hours of English a week. As the language is not 
their mother tongue, the students are not only learning to read, but they are also learning new vocabulary and grammar. This amount of learning in a maximum of an hour a day is not enough for a child to be able to master the language. I believe that $\% 50$ of phonological awareness is quite an achievement in this circumstance. If the female students were exposed to longer hours of English daily, they would most probably achieve \%80 or more in their reading. As for the male students, it seems that they need to have a different set of activities to grab their interest and raise the percentage of phonological awareness.

\section{Conclusion:}

This study represented the advantages of teaching phonics and the usefulness of the methods used to teach phonics in primary schools in Kuwait. The study focused on graduates of first and second grade primary school students from both genders. The participants were chosen randomly as were the schools. The only criterion required was that the student has not had formal English tutoring prior to entering school.

The teachers who were teaching English in the primary schools that have participated in this research did not have proper training to teach phonics. All they had was the teachers' guideline. It appeared that although they did depend on the systematic teaching of phonics, which highly increases the students' ability to learn their phonics, they did not use a variation of techniques to teach phonics. Their method of teaching phonics depended on pointing to the letters written on the board or on a poster and sounding them out. The students, on their turn, would repeat the sound of the letter heard. Making phonics fun would highly increase the learning scope in the same amount of time provided for the teachers. Group play or card organization are a couple of different ways phonics could be taught. It is highly recommended that teachers always integrated phonics in their daily teaching, and variation is the key of fast phonics learning. Especially when it 
comes to gender differences, it is well known that male students learn with variation as their tolerance to repetition is less than the female students' tolerance. Therefore, when methods are varied they not only become suitable for all children regardless of their learning abilities, they also become equip for gender differences.

The sounds that were tested were English sounds that are not part of the Arabic phonetic system (/p/,/v/,/tg/). The study focused on both the ability to identify the sounds when heard and the ability to realize the sounds when reading. The data was then compared and analyzed in terms of grade and gender. The participants sat alone with the researchers and participated willingly, enjoying taking part in the research.

The results in general have shown that female students in both grades are significantly better at realizing and identifying the English sounds than male students. This has been known as a general fact in many studies; namely, female students are better at learning generally and learning language specifically than male students (Costa et al, 2001; Mullis et al 2003, Feingold, 1994).

The percentage of the female students' realization and identification of phonic sounds is quite high, which reflects the fact that the methods used in teaching phonics in Kuwaiti primary schools is successful and the teachers are aware of the importance of delivering phonological awareness. However, more time to teach English is recommended as this will increase their exposure to the language, and therefore, their ability to read.

This study has shown that male students, who are highly active, are ignored and therefore, gain minimal learning in class compared to their female counterpart. The issue that has come to surface is not only that the teaching of phonics should be taught in a different way, but also the instructors should receive different guidelines for male students which helps them deal with active kids and encourage them to learn. Through the assistance and experience 


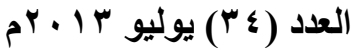

of psycho-educational experts, special phonic activities can be suggested for male students bearing in mind their impatience and active nature.

Overall, teaching reading through phonics has shown to be advantageous as phonologically aware students were able to sound out words they do not know. Students who were aware of their phonics displayed the ability to sound out the words in phonological pairs or single sounds which were taught to them in school. I believe with the use of appropriate methods of teaching reading and the availability of sufficient time, first and second grade primary school students in Kuwaiti public schools will be able to read fluently.

\section{References:}

Al-Darwish, S. (2006) An Investigation of Teacher's Perceptions of the English Language Curriculum in Kuwaiti Elementary Schools. PhD Thesis.The College of Education, University of Denver, Denver.

Al-Haji, B. (2004) Investigating the Primary English Language Classrooms in Kuwait: focusing on pupil-teacher interaction.PhD Thesis, University of Liverpool, UK.

Al-Naqeeb, Kh. (2003) "Present and future of Gulf social conditions".In Challenges of Globalization and the Futureof the Family in Arabian Gulf (preliminary reading). B. Al-Najjar (ed). Kuwait.

Barton, A. (1996) "Words of comfort for males". Times Educational Supplement. 22 March.

Beck, I. L. (2006) Making Sense of Phonics.Guilford Press: New York.

Costa, P.; Terraciano, A. \& R. McCrae "Gender differences in personality traits across cultures, robust and surprising findings". Journal of Personality and Social Psychology, vol. 81, issue 2, pp. 322-331.

Eccles, J.; Wigfield, A., Harold, R. and B. Blumenfield (2008) "Age \& gender differences in children's self and task perceptions during elementary school". Child Development, vol. 46, issue 3, pp.830-847.

Ehri, L. C. (1991) Learning to read and spell words. In L. Rieben\& C. Perfetti (eds.) Learning to Read: Basic Research and its Implications, pp.57-73. Hillsdale, NJ: Erlbaum.

Feingold, A (1994) "Gender Differences in Personality: a meta-analysis". Psychology Bulletin, vol.116. pp. 429-456. 
Ferrara, M. (2009) "The student and the teacher: making a match in the singlegender classroom" Advances in Gender and Education, M. Ferrara ed. Vol. 14 (21), pp. 14-21.

Garfield, A (1992) Teach your Child to Read. Vermillion Publications: London.

Gentry, M.; Gable, R.K. \& M. G. Rizza (2002) "Students' perception of classroom activities: Are there grade-level and gender differences". Journal of Education Psychology, vol. 94 (3), pp. 539-544.

Goouch U, K. \&Lambirth, A. (2008) Understanding Phonics and the Teaching of Reading: critical perspectives. Open University Press: London.

Gurian, M.; Stevens, K. \& K. King (2008) Strategies for Teaching Boys \& Girls -Elementary Level. Jossey-Bass: San Francisco.

Johnston, R. and Watson, J. (2007) Teaching Synthetic Phonics.Learning Matters Press: London.

Lewis, M. \& Ellis, S. (2006) Phonics: practice, research and police. Sage Publications: London.

MacNellage, P.; Davis, B. \& C. Martyear (1997) "Babbling the first words: Phonetic similarities and differences". Speech Communication, vol. 22, issue 2-3, pp. 269-277.

OECD (2003) Literacy Skills for the World of Tomorrow. U.K.

Rieben, Laurence, and Charles A. Perfetti (eds) (1991). Learning to read: Basic research and its implications. Hillsdale, NJ: Lawrence Erlbaum.

Pinnell, G. \&Fountas I.C. (1998) Word Matters: Teaching Phonics and Spelling in the Reading/Writing Classroom. Heinemann Educational Books: U.S.A.

Savage, J. (2006) “Three approaches to phonies”.Retrieved August 21, 2011 from

http://www.epsbooks.com/downloads/articales/Three_Approaches_Phonics.pdt

Savage, J. (2007) Sound it Out! Phonics in a Comprehensive Reading Program. $3^{\text {rd }}$ ed.Mcgraw-Hill: Boston.

Sever, F. P. (1994) The Progressive Speller. Boston: D. C. Heath and Co.

Steinberg, D. \&Sciarini, N. (2006) An Introduction to Psycholinguistics. $2^{\text {nd }}$ ed. Pearson Education Limited: Harlow.

Wilkinson, L. C. \& C. B. Marret (1985) Gender Influences in Classroom Interaction. Academic Press: Orlando. 
العدد (ع ب) يوليو r 1 • r

Appendices

Appendix A: list of words

Appendix B: story 1

Appendix C: story 2 
Appendix A

\begin{tabular}{|l|l|l|}
\hline Word read by instructor & \multicolumn{1}{c|}{ Choice A } & \multicolumn{1}{c|}{ Choice B } \\
\hline Live & Life & Live \\
\hline Chips & Chips & Ships \\
\hline Fan & Van & Fan \\
\hline Pen & Pen & Ben \\
\hline Voice & Voice & Foice \\
\hline Watch & Watch & Watsh \\
\hline Bank & Bank & Pank \\
\hline Cave & Cave & Cafe \\
\hline Chocolate & Shocolate & Chocolate \\
\hline Lip & Lib & Lip \\
\hline Face & Vace & Face \\
\hline Stove & Stove & Stofe \\
\hline Rich & Rish & Rich \\
\hline Rob & Rop & Rob \\
\hline Vet & Vet & Fet \\
\hline Match & Matsh & Match \\
\hline Pet & Bet & Pet \\
\hline Riff & Rivv & Riff \\
\hline Van & Fan & Van \\
\hline Paint & Baint & Paint \\
\hline Catch & Catsh & Catch \\
\hline Brain & Brain & Prain \\
\hline Love & Lofe & Love \\
\hline Children & Children & Shildren \\
\hline Pencil & Bencile & Pencile \\
\hline Oven & Oven & Ofen \\
\hline Shine & Chine & Shine \\
\hline Ball & Ball & Pall \\
\hline Change & Shange & Change \\
\hline Apple & Apple & Able \\
\hline Fill & Vill & Fill \\
\hline & & \\
\hline
\end{tabular}


العدد (ع ب) يوليو r 1 + ب م

\begin{tabular}{|l|l|l|}
\hline Have & Have & Hafe \\
\hline Top & Top & Tob \\
\hline Fat & Fat & Vat \\
\hline Chase & Shase & Chase \\
\hline Play & Blay & Play \\
\hline Save & Safe & Save \\
\hline Shave & Chave & Shave \\
\hline Boat & Boat & Poat \\
\hline Hatch & Hatch & Hatsh \\
\hline Nap & Nab & Nap \\
\hline
\end{tabular}

\section{Appendix B}

Things They

Like

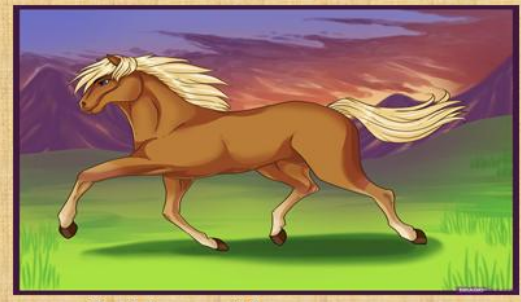

Swish....swish...

The pony loves to run.
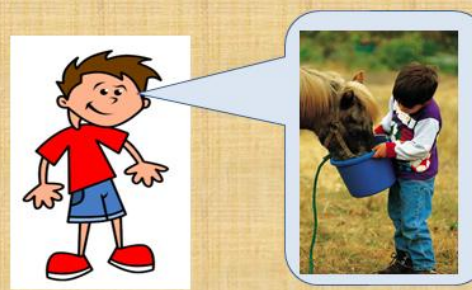

See Chip. He likes ponies.

Chip chases ponies.
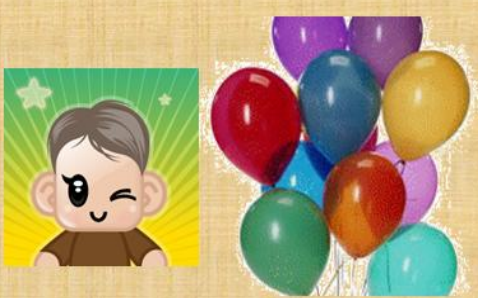

See Richie. He likes balloons. Up! Up! Up! They go. 
العدد (ع r) يوليو ب 1 • r م

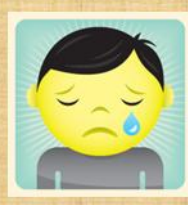

The balloons go up.

Stop! Stop! Says Richie.
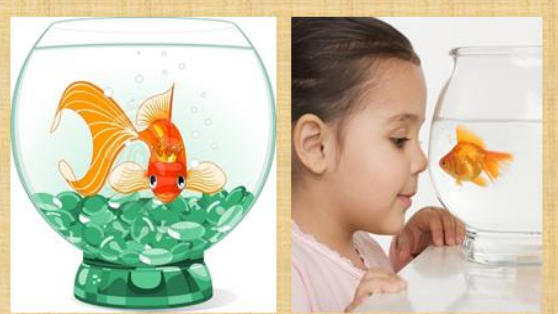

See Viv. She loves her fish.

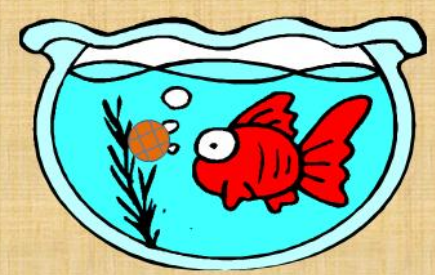

Viu puts a ball with the fish.

Fishes don't play ball. 
العدد (ع ب) يوليو r 1 • r

Appendix B

- 31 - 
العدد (ع ب) يوليو r 1 • ب م
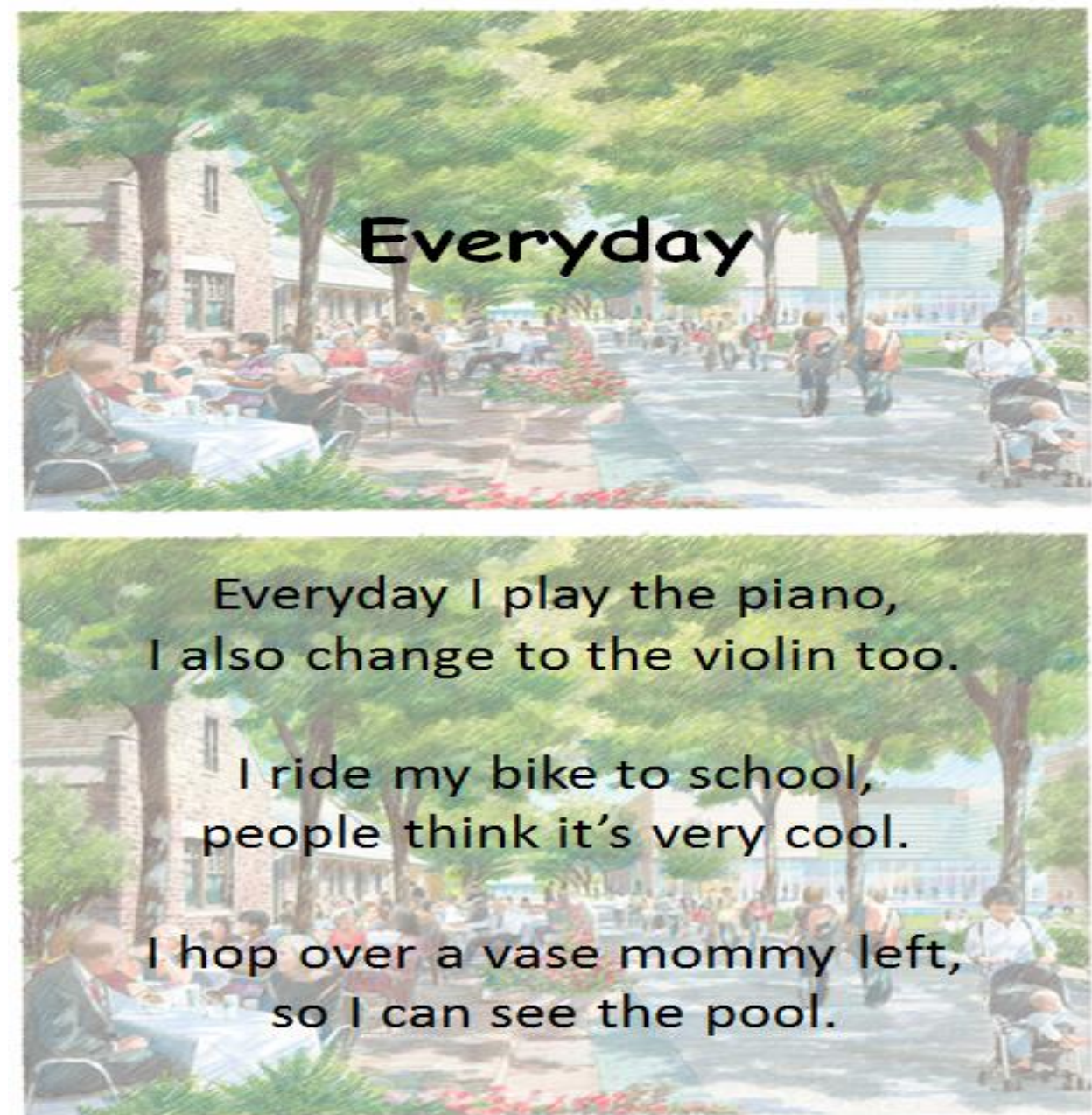


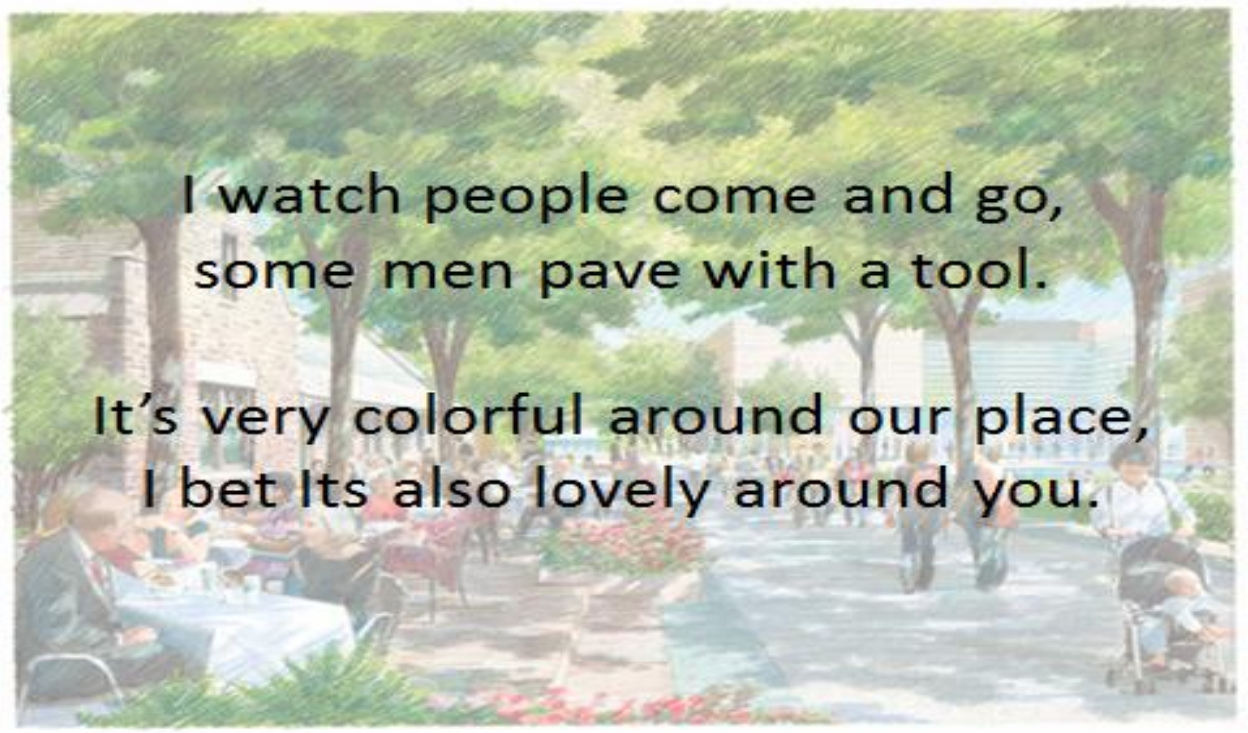




\section{Authors:}

Dr. Hanan Taqi (first author): Master's Degree in TESOL from Newcastle University - UK, 2000. Ph.D. in Phonology from Newcastle University - UK, 2010.Assistant professor in the College of Basic Education in Kuwait since 2010.

Dr. SalwaAldarwish: Master's Degree in Bilingual Multicultural Education from The university of Colorado Boulder - USA. Ph.D. in Curriculum and Instruction from the University of Denver USA.Assistant professor in the College of Basic Education since 2006.

Dr. TaibaSadiq:Master's degree in CAL from the University of San Francisco.Ph.D.in CALL from Queen's College - UK. Assistant professor in the College of Basic Education since 2003.

Dr. BadriaAlhaji: Master's in Education from Manchester University UK. Ph.D. in Teaching Methods from Liverpool University UK.Assistant professor in the College of Basic Education in Kuwait since 2004. 